
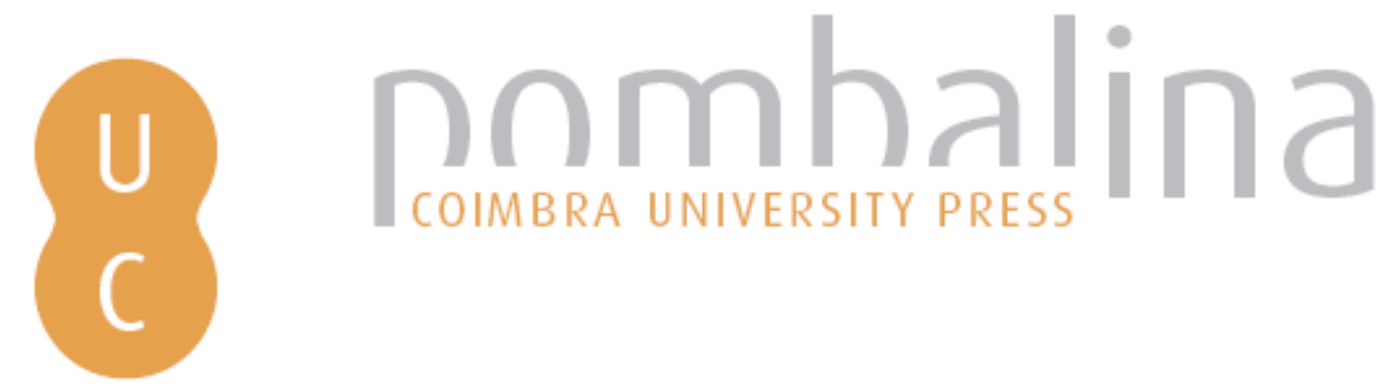

\title{
The consideration of arson for forest fires caused by traditional uses of fire prohibited in Spain: a problem under discussion
}

Autor(es): $\quad$ Martínez-Navarro, José Mª̣; Vázquez-Varela, Carmen

Publicado por: Imprensa da Universidade de Coimbra

URL

persistente: URI:http://hdl.handle.net/10316.2/44648

DOI: $\quad$ DOI:https://doi.org/10.14195/978-989-26-16-506_131

Accessed : $\quad$ 26-Apr-2023 13:20:22

A navegação consulta e descarregamento dos títulos inseridos nas Bibliotecas Digitais UC Digitalis, UC Pombalina e UC Impactum, pressupõem a aceitação plena e sem reservas dos Termos e Condições de Uso destas Bibliotecas Digitais, disponíveis em https://digitalis.uc.pt/pt-pt/termos.

Conforme exposto nos referidos Termos e Condições de Uso, o descarregamento de títulos de acesso restrito requer uma licença válida de autorização devendo o utilizador aceder ao(s) documento(s) a partir de um endereço de IP da instituição detentora da supramencionada licença.

Ao utilizador é apenas permitido o descarregamento para uso pessoal, pelo que o emprego do(s) título(s) descarregado(s) para outro fim, designadamente comercial, carece de autorização do respetivo autor ou editor da obra.

Na medida em que todas as obras da UC Digitalis se encontram protegidas pelo Código do Direito de Autor e Direitos Conexos e demais legislação aplicável, toda a cópia, parcial ou total, deste documento, nos casos em que é legalmente admitida, deverá conter ou fazer-se acompanhar por este aviso.

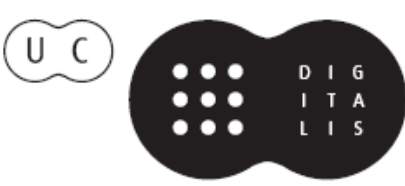




\section{ADVANCES IN}

\section{FOREST FIRE RESEARCH}

\section{8}

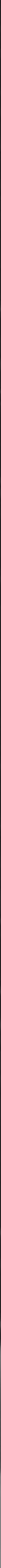




\title{
The consideration of arson for forest fires caused by traditional uses of fire prohibited in Spain. A problem under discussion.
}

\author{
José $\mathrm{M}^{\mathrm{a}}$ Martínez-Navarro ${ }^{1 *}$; Carmen Vázquez-Varela ${ }^{2}$ \\ ${ }^{1}$ PhD in Geography. Independent Consultant, \{josemaria.martineznavarro@gmail.com*\} \\ ${ }^{2}$ Department of Geography, University of Castilla-La Mancha. Avenida de los Alfares, 44, 16071 \\ Cuenca, Spain, \{carmen.vazquez@uclm.es\}
}

\begin{abstract}
In some southern European countries, and in particular in Spain, the custom, rooted in the paradigm of the exclusion of fire, of considering and classifying in official statistics as intentional forest fires all ignitions generated by prohibited agricultural uses related to the traditional culture of fire, is maintained. This custom generates, from our perspective, a series of problems that deserve to be considered before deciding whether or not to maintain this criterion in our official statistical information systems. These problems are, first of all, the lack of uniformity in the classification criteria for the European EFFIS database, which means that the results for the different Member States are not comparable, thus rendering the effort made to produce and maintain a common European statistic meaningless, as well as the possibilities for analysing the problem associated with EFFIS.

Secondly, and already at the national level, this criterion distorts any rigorous analysis of the causes of ignitions, and without a rigorous initial analysis it is difficult to design effective prevention policies. Thirdly, the criterion, together with the sensationalist treatment of fires by the media, has created a monumental problem in public opinion, which does not understand what is happening, and which ends up generating a political problem. Politicians are struggling to lead this public opinion, and at present this is leading to an escalation of efforts in the police and judicial fight against a crime problem that does not really exist, to the detriment of real prevention policies based on Integrated Fire Management. It is precisely the latter that have been analysed in the European project FIREPARADOX and defended by the majority of experts and technicians today. Finally, the maintenance of this criterion is a clear disadvantage for the understanding by the non-expert public of the postulates of fire ecology, making the efforts that various organizations are beginning to make in this regard very complicated.

In relation to the sources and methodology used in this research, we have analysed the criteria for classifying the causes of forest fires used in the database of the Spanish General Statistics on Forest Fires (EGIF) and their problematic adaptation to the harmonized classification scheme of fire causes in the EU adopted for the European Fire Database of EFFIS. Subsequently, we compared the results of the current classification of the Spanish General Statistics of Forest Fires (EGIF) with those of an adaptation of the same prepared using the harmonized classification scheme of EFFIS. Finally, we have compared the results obtained from the two classifications with the data published by the Attorney General's Office on the intentionality of forest fires in judicial investigations over the last decade.
\end{abstract}

Keywords: Arson; traditional uses of fire; Spanish General Statistics on Forest Fires (EGIF); harmonized classification scheme of EFFIS; Spain.

\section{Introduction: The sterility of the causal-guilt approach}

Many of the specialists (scholars and technicians) and studies consulted for the Spanish case agree on the inevitable sterility of the approach that addresses the problem of forest fires from a causal-guilt relationship, especially in the case of the rural population and traditional/cultural uses. The results of the Socioeconomic Study of the Regions included in the Plan of Preventive Measures against Forest Fires of Castilla y León (Plan 42) (Molinero et al., 2008a) conclude that, for farmers, fire has always been used as a management tool for forests and their uses, and although it may seem contradictory in 
the context of the current abandonment of rural areas, fires for the regeneration of pastures continue to be one of the main reasons for forest fire in the fire reports of the region. In addition to this, there are conflicts with the administration over the control and use of forest products -pasture, firewood, wood, mushrooms and hunting- without forgetting the abandonment of arable land and the reduction of livestock pressure, which favour the advance of the bush, and the scarce or null interest in the exploitation of forest lands due to the sharp fall in the price of wood (Molinero et al. 2008b).

In the same vein, a previous work on Galicia by Professor Pérez Vilariño coincided with the group led by Fernando Molinero, who pointed out that the technocratic approach that does not contemplate cultural aspects is particularly sterile for understanding the phenomenon. In the opinion of the authors of the study, to attempt to explain the vast majority of forest fires by the same diffuse cause deliberateness or intentionality - is tantamount to not clarifying anything. "Resorting to armed gangs and other similar forms of conspiracies or mythical imaginaries, without being able to prosecute more than some poor man, who can hardly be accused of any fire, is the most convincing proof of the blurring of the causal-guilt model" (Pérez Vilariño and Delgado Fernández, 1995: 110).

Against this background, this contribution seeks to analyse the problem of the classification in the Spanish forest fire database (EGIF) of all cultural burns that are prohibited or carried out without a permit and that lead to forest fires, such as arson. This decision results in a problem of comparability and lack of uniformity in relation to the classification criteria of the European EFFIS (European Forest Fire Information System) database.

Secondly, and already at the national level, this criterion distorts any rigorous analysis of the causes of ignitions, and without a rigorous initial analysis it is difficult to design effective prevention policies. Thirdly, the criterion, together with the sensationalist treatment of fires by the media, has created a monumental problem in public opinion, which does not understand what is happening, and which ends up generating a political problem. Politicians are struggling to lead this public opinion, and at present this is leading to an escalation of efforts in the police and judicial fight against a crime problem that does not really exist, to the detriment of real prevention policies based on Integrated Fire Management.

To carry out this analysis we have used both national data and data from the elaboration of the Doctoral Dissertation of the first signatory of this contribution (Martínez Navarro, 2017), which focus on the region of Castilla-La Mancha. The data handled come from the regional historical database on forest fires (EGIF) for the period 1968-2013, from the national EGIF 2011-2013, and from the reports of the Attorney General's Office for the Environment for the period 2007-2015.

\section{The methodological problem of disaggregating causes and motivations}

The enumeration of a long list of causes (36 categories in the Negligence and Accidents group) prevents us from seeing the grouping and relevance of the negligence related to traditional rural culture, which constitutes one of the central nuclei to be analyzed in order to understand the causality of forest fires, as demonstrated by all the qualitative research carried out in our country (APAS and IDEM, 2004; Castro et al., 2007; Molinero et al., 2008a; Molinero et al., 2008b; Pérez Vilariño and Delgado Fernández, 1995; Priego and Lafuente, 2007; Vélez Muñoz, 1999).

The same problem can be found when analyzing the motivations of arson, which are in a database field other than the disaggregation of negligence. Since 1989, the Fire Report has received the addition of a new field associated with deliberate causation, which is labelled as "motivation" and which establishes as categories an exhaustive series of motivations that can lead a person to deliberately cause a forest fire. In 1989 this repertoire included 16 types of motivation. In the next update of the report form, i.e. from 1998 onwards, 7 new types of motivation were added, for a total of 24 (CLIF, 1997a; CLIF 1997b). 
We can see that for $73 \%$ of the deliberate forest fires included in the regional EGIF database, the motivation is unknown, a logical question if we take into account that in order to know the motivation we have to identify the arsonist. However, we believe that a thorough analysis of the remaining $27 \%$ should be carried out in order to better understand the problems behind the intentionality from a territorial point of view.

To do this, we should start by pointing out that the motivation series presents the same methodological problem as the description of cause associated with the Accidents and Negligence group: it has too many categories and many of them lack statistical significance because they are represented by a minimum number of fire reports. For this reason, it was decided to propose a model of reasoned groupings that would allow us to generate more clarifying categories from a territorial perspective and at the same time with some statistical significance. We consider that a model already exists that meets these requirements and for which the necessary recoding of the EGIF database is standardised, which is none other than the new European fire database EFFIS to which the Spanish Ministry incorporates the EGIF information with a public access protocol.

The EFFIS database is better oriented to analysis than the EGIF one because it classifies causality into three hierarchical levels instead of grouping causes into broad categories and then incorporating disaggregation for negligence and deliberate ones into separate fields, so that any fire can be analysed at any of the three levels, an issue that solves the problem of disaggregation without renouncing the detailed information contained in the EGIF.

However, it is the formally recording (harmonization) of the "Spanish" causality of EGIF in the international database that offers us some conceptual and legal doubts that we will expose in the analysis of the corresponding EFFIS categories, especially in the sense of keeping the agricultural and livestock burns without permission within groups with other criminal causes contrary to the criteria defined by the JRC (Joint Research Centre).

\section{The EFFIS database}

In 1998, the Joint Research Centre (JRC), a Directorate-General of the European Commission (EC), and the only service directly responsible for research, created a research group to work specifically on the development and implementation of advanced methods for forest fire risk assessment and mapping of burnt areas at European level. In addition, a first meeting of the "Forest Fire Experts Group" was held in the same year. All these activities led to the development of the European Forest Fire Information System (EFFIS), which became operational in 2003 to provide improved information and contribute to a common understanding of the origin of forest fires in Europe, while preserving as far as possible the historical databases of each country and exploiting the information available at the highest level of detail.

\section{The structure of the EFFIS database}

Traditionally, until the introduction of the new harmonised classification structure supervised by the JRC, the European-wide recording of the causes of forest fire has been carried out using, since 1992, a simple scheme of four main causality categories for forest fires: arson, accidental/negligent, natural and unknown. This classification system conflicted with the collection and classification model of the different European countries, which was usually much more detailed and for which there was no proposal for harmonisation, so the comparative or cross-sectional analyses were very complex.

The need for a harmonised European classification structure, more disaggregated than the original four categories, and which could be incorporated into the EFFIS fire database, was a pressing need for further progress in improving information and shared knowledge on the origin of forest fires in Europe. 
The new classification structure has been designed to be applied with limited changes to each of the data collection schemes of the different EU countries, preserving as far as possible the historical data series of each state and exploiting the level of detail of the available information. The structure is hierarchical and is constructed from 29 classes of fire causes, 8 groups and 6 major categories (see Table 1). The explicit declaration of the level of certainty in the allocation of the cause of the forest fire is also introduced as a key element in the new model. Finally, it is expected that the new causality classification scheme will be progressively adopted by the countries participating in the EFFIS network and therefore integrated into the registration system of the European forest fire database, with significant added value for the knowledge of the technical and scientific community on the origin of forest fires on the continent.

Table 1 - Classes, groups and categories of the harmonized fire causes classification scheme Source: Joint Research Centre, 2013: 10.

\begin{tabular}{|c|c|c|}
\hline CATEGORY & GROUP & CLASS \\
\hline EFFIS 1 & EFFIS 2 & EFFIS 3 \\
\hline 100 Unknown & 100 Unknown & 100 Unknown \\
\hline \multirow[t]{3}{*}{200 Natural } & \multirow[t]{3}{*}{200 Natural } & 201 Lightning \\
\hline & & 202 Volcanism \\
\hline & & 203 Gas emission \\
\hline \multirow[t]{7}{*}{300 Accident } & \multirow[t]{7}{*}{300 Accident } & 301 Electrical power \\
\hline & & 302 Railroads (Railways) \\
\hline & & 303 Vehicles \\
\hline & & 304 Works \\
\hline & & 305 Weapons (firearms, explosives, etc.) \\
\hline & & 306 Self-ignition (auto-combustion) \\
\hline & & 307 Other accident \\
\hline \multirow[t]{9}{*}{400 Negligence } & \multirow[t]{5}{*}{410 Use of fire } & 411 Vegetation management \\
\hline & & 412 Agricultural burnings \\
\hline & & 413 Waste management \\
\hline & & 414 Recreation \\
\hline & & 415 Other negligent use of fire \\
\hline & \multirow[t]{4}{*}{420 Use of glowing objects } & 421 Fireworks, firecrackers and distress flares \\
\hline & & 422 Cigarettes \\
\hline & & 423 Hot ashes \\
\hline & & 424 Other use of glowing object \\
\hline \multirow[t]{8}{*}{500 Deliberate } & \multirow[t]{6}{*}{510 Responsible (arson) } & 511 Interest (profit) \\
\hline & & 512 Conflict (revenge) \\
\hline & & 513 Vandalism \\
\hline & & 514 Excitement (incendiary) \\
\hline & & 515 Crime concealment \\
\hline & & 516 Extremist \\
\hline & \multirow[t]{2}{*}{520 Irresponsible } & 521 Mental illness \\
\hline & & 522 Children \\
\hline 600 Rekindle & 600 Rekindle & 600 Rekindle \\
\hline
\end{tabular}




\section{Re-encoding of the Spanish forest fire database to the EFFIS harmonised classification}

As noted in previous sections, we have chosen to recode the information collected in the EGIF using as classification categories, groups and classes those proposed in the new harmonised European classification system. The latter provides a simplified model for analysis and allows us to compare national data and perspectives without entering into aspects of legal liability and prosecution, which we will address later.

Thus, the set of Forest Fire Reports gathered in the regional base for the period 1968-2013 are included in one of the six pre-established categories (Figure 1) with two particularities, the first of which refers to the fact that a small part of the negligence within the EGIF, fires caused by children, would pass to the group of deliberate fires if we adhered to the EFFIS criteria, since the harmonised European base includes them in this group although the perpetrators are considered irresponsible. It is a small group of 100 fire reports that we have distinguished by maintaining the green color but adding its weight to the group of fire reports of deliberate origin.

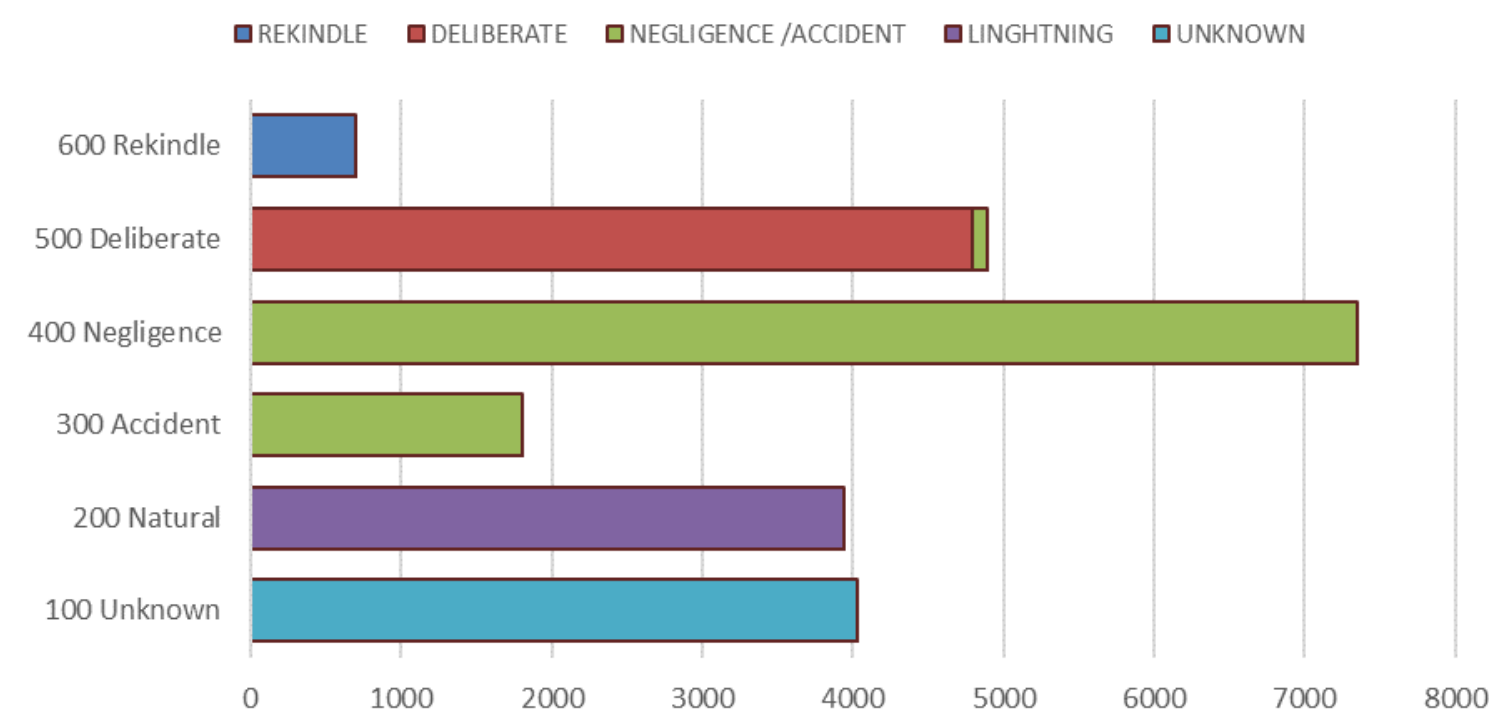

Figure 1 - Harmonisation of "Causes Group" EGIF and EFFIS1 categories. Number of fire reports. Castilla-La Mancha 1968-2013

The second particularity refers to a fact that we will develop in depth below, but which we anticipate by commenting that a large part of the fires included in the category of deliberate fires in the harmonised Spanish base, vegetation management and those derived from agricultural burnings and waste management carried out without the appropriate burn permits, are included by the rest of the countries (as can be seen from the approach of the harmonised base itself) in the category of fires due to negligence. The only two countries that include these fires of cultural origin, tied to the rural world, in the category of arson are Spain and Italy. In other words, in Spain any forest fire caused by agricultural burnings or due to vegetation management that has been carried out without the required permits or outside the limited period for this purpose is automatically considered an arson.

Having made this fine-tuning, the harmonised classification of the EFFIS3 categories would be as shown in Table 2. Continuing with the adjustments between the harmonized database and the original EGIF, it is necessary to remember that, since 2011, the group of Negligent and accidental causes appears with two labels in which the numbers 2 for negligence and 3 for accidents precede the name, as shown in the table below, a division that is perfectly consistent with the EFFIS coding. 
Table 2 - Number of Forest Fire Reports by EFFIS3 classification and EGIF Category Groups. Castilla-La Mancha 1968-2013

\begin{tabular}{|c|c|c|c|c|c|c|}
\hline & 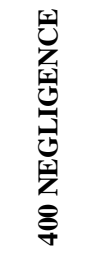 & 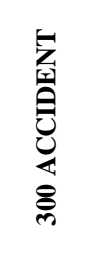 & $\begin{array}{l}z \\
0 \\
z \\
z \\
3 \\
8 \\
0\end{array}$ & 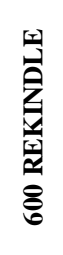 & 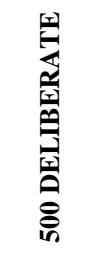 & טلِ \\
\hline 100 Unknown & & & 4,033 & & & \\
\hline 201 Lightning & & & & & & 3,942 \\
\hline 301 Electrical power & & 398 & & & & \\
\hline 302 Railroads (Railways) & & 155 & & & & \\
\hline 303 Vehicles & & 149 & & & & \\
\hline 304 Works & & 1,076 & & & & \\
\hline 305 Weapons (firearms, explosives, etc.) & & 32 & & & & \\
\hline 400 Negligence (unspecified) & 779 & & & & & \\
\hline 411 Vegetation management & 1,517 & & & & & \\
\hline 412 Agricultural burnings & 2,639 & & & & & \\
\hline 413 Waste management & 1,013 & & & & & \\
\hline 414 Recreation & 703 & & & & & \\
\hline 421 Fireworks, firecrackers and distress flares & 36 & & & & & \\
\hline 422 Cigarettes & 1,218 & & & & & \\
\hline 424 Other use of glowing object & 12 & & & & & \\
\hline 500 Deliberate (unspecified) & & & & & 3,423 & \\
\hline 511 Interest (profit) & & & & & 1,002 & \\
\hline 512 Conflict (revenge) & & & & & 169 & \\
\hline 513 Vandalism & & & & & 142 & \\
\hline 514 Excitement (incendiary) & & & & & 3 & \\
\hline 515 Crime concealment & & & & & 1 & \\
\hline 521 Mental illness & & & & & 50 & \\
\hline 522 Children & 101 & & & & & \\
\hline 600 Rekindle & & & & 131 & & \\
\hline
\end{tabular}

\section{Harmonisation for the "500 Deliberate" category of the EFFIS database}

The fires classified by the Spanish administration as deliberate occupy the second place in the region according to the cause of the fire (4,790 fire reports between 1968 and $2013-4,891$ if we add fires caused by children - which is equivalent to $21 \%$ of the total) but the first by the extent of the burned surface $(41 \%)$. These data, together with its exponential growth trend, show that arson is currently one of the biggest problems to be solved and one of the most difficult to tackle, because to set fire is easy but to prevent this type of event is far from being so. On the other hand, the classes of fire causes included in this group translate an approach to the problem from the paradigm of fire exclusion that conditions the territorial management of anthropogenic risk of ignition and is the source of numerous conflicts between the administration and the local population living in the rural world. In addition, the motivation for deliberate forest fires is particularly poorly known: only $28.5 \%$ of deliberate cases are cleared up (as can be seen from the table below, of the 4,790 fire reports in the 
arson group 3,423 appear in the "unspecified" class). Moreover, as the motivations are set out, even today, they are not always interpreted by the forest officials who elaborate the fire reports in the same way. The motives are understood according to the peculiarities of the local reality, the custom of its forestry section or simply the experience that each one has (Carracedo Martín et al., 2009). When making a complaint, it is difficult to consider this information valid because of the burden of intuition it entails. For this reason, the work of the Forest Fire Investigation Brigades (BIIF) is becoming increasingly important.

Table 3 - Harmonisation for the "500 Deliberate" category of the EFFIS database. Castilla-La Mancha 1968-2013 (in red "cultural" causes)

\begin{tabular}{|c|c|c|c|c|c|}
\hline EFFIS/Motivations & $\begin{array}{l}\text { Number of } \\
\text { fire reports }\end{array}$ & $\begin{array}{c}\text { Total area } \\
\text { burned }\end{array}$ & $\begin{array}{l}\text { Average burned } \\
\text { surface area }\end{array}$ & $\begin{array}{l}\text { Maximum area } \\
\text { burned by fire }\end{array}$ & $\begin{array}{l}\text { Standard deviation } \\
\text { of burned surface }\end{array}$ \\
\hline \multicolumn{6}{|l|}{500 Deliberate (unspecified) } \\
\hline \multicolumn{6}{|l|}{500 Deliberate (unspecified) } \\
\hline Other motivations & 71 & 282.8 & 4.0 & 74.0 & 11.8 \\
\hline Unspecified & 3,352 & $75,260.0$ & 22.5 & $14,225.0$ & 274.6 \\
\hline \multicolumn{6}{|l|}{510 Responsible (arson) } \\
\hline \multicolumn{6}{|l|}{511 Interest (profit) } \\
\hline $\begin{array}{l}\text { Earning wages in forest fire } \\
\text { fighting or restoration }\end{array}$ & 4 & 68.4 & 17.1 & 57.0 & 27.0 \\
\hline $\begin{array}{l}\text { To promote the production of } \\
\text { forestry products }\end{array}$ & 1 & 0.01 & 0.01 & 0.01 & \\
\hline To gain changes in land use & 9 & 37.5 & 4.2 & 22.4 & 7.2 \\
\hline $\begin{array}{l}\text { Triggered to scare away animals } \\
\text { (wolves, wild boars) }\end{array}$ & 25 & 60.7 & 2.4 & 33.7 & 6.6 \\
\hline Agricultural burnings & 572 & $1,505.2$ & 2.6 & 300.0 & 13.3 \\
\hline $\begin{array}{l}\text { Provoked by hunters to facilitate } \\
\text { hunting }\end{array}$ & 116 & $1,274.9$ & 11.0 & 338.0 & 39.3 \\
\hline $\begin{array}{l}\text { Caused by political groups to create } \\
\text { social unrest }\end{array}$ & 2 & 0.3 & 0.1 & 0.2 & 0.1 \\
\hline $\begin{array}{l}\text { Herders and ranchers provoke them } \\
\text { to regenerate the grass }\end{array}$ & 269 & $1,448.7$ & 5.4 & 200.0 & 19.7 \\
\hline \multicolumn{6}{|l|}{512 Conflict (revenge) } \\
\hline Opposition to reforestation & 3 & 184.1 & 61.4 & 180.0 & 102.7 \\
\hline $\begin{array}{l}\text { Disagreements on the ownership of } \\
\text { public or private forests }\end{array}$ & 1 & 0.01 & 0.01 & 0.01 & \\
\hline $\begin{array}{l}\text { To force resolutions of consortia or } \\
\text { agreements }\end{array}$ & 4 & 12.8 & 3.2 & 5.0 & 1.8 \\
\hline Incited against hunting restrictions & 70 & $2,893.6$ & 41.3 & $1,495.0$ & 184.8 \\
\hline Caused by vengeance & 79 & $11,434.0$ & 144.7 & $5,489.4$ & 709.3 \\
\hline $\begin{array}{l}\text { Opposition to the creation or } \\
\text { existence of protected natural areas }\end{array}$ & 8 & 46.1 & 5.8 & 38.3 & 13.2 \\
\hline $\begin{array}{l}\text { Retaliation by reducing public } \\
\text { investment in forests }\end{array}$ & 4 & 16.2 & 4.1 & 15.0 & 7.3 \\
\hline \multicolumn{6}{|l|}{513 Vandalism } \\
\hline Vandalism & 142 & 653.9 & 4.6 & 100.0 & 14.4 \\
\hline \multicolumn{6}{|l|}{514 Excitement (incendiary) } \\
\hline To admire the work of fire fighting & 3 & 41.1 & 13.7 & 40.0 & 22.8 \\
\hline \multicolumn{6}{|l|}{515 Crime concealment } \\
\hline $\begin{array}{l}\text { Caused by criminals, etc. to distract } \\
\text { law enforcement officials }\end{array}$ & 5 & 2.7 & 0.5 & 2.0 & 0.9 \\
\hline \multicolumn{6}{|l|}{516 Extremist } \\
\hline $\begin{array}{l}\text { Caused by political groups to create } \\
\text { social unrest }\end{array}$ & 2 & 0.29 & 0.125 & 0.2 & 0.5 \\
\hline
\end{tabular}




\begin{tabular}{|c|c|c|c|c|c|}
\hline EFFIS/Motivations & $\begin{array}{l}\text { Number of } \\
\text { fire reports }\end{array}$ & $\begin{array}{c}\text { Total area } \\
\text { burned }\end{array}$ & $\begin{array}{l}\text { Average burned } \\
\text { surface area }\end{array}$ & $\begin{array}{l}\text { Maximum area } \\
\text { burned by fire }\end{array}$ & $\begin{array}{l}\text { Standard deviation } \\
\text { of burned surface }\end{array}$ \\
\hline $\begin{array}{l}\text { Pseudo-Religious Rites and } \\
\text { Satanism }\end{array}$ & 0 & 0 & 0 & 0 & 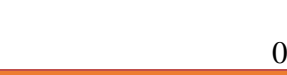 \\
\hline \multicolumn{6}{|l|}{520 Irresponsible } \\
\hline \multicolumn{6}{|l|}{521 Mental illness } \\
\hline Caused by pyromaniacs & 50 & $2,188.0$ & 43.8 & $1,392.0$ & 204.1 \\
\hline \multicolumn{6}{|l|}{522 Children } \\
\hline Negligence (Children's Games) & 101 & 206.1 & 2.0 & 60.3 & 6.7 \\
\hline Cumulative total & 4,891 & 97,617 & 20.0 & 14,225 & 247.0 \\
\hline
\end{tabular}

The EFFIS 500 Deliberate category, like the Negligence category, differentiates between two major groups, in this case on the basis of the criminal liability of the act, which presents problems of harmonisation for all the national classifications integrated into the European network, and in particular with the EGIF, as we will analyse below. This differentiation in terms of liability generates two groups of causes: the Responsible (arson) and the Irresponsible 510, which includes those fires caused by people who cannot be charged because they are not criminally responsible for their actions, minors (criminal law) and certain mentally ill people, an issue that changes depending on how nonliability is addressed in the criminal legislation of each country.

For this reason we find two EFFIS3 classes in the "Irresponsible" group, 522 Children and 521 Mentally ill. As can be seen in the table above, the "Responsible (arson)" group includes six EFFIS3 classes, the first two being 511 Interest (profit) and 512 Conflict (revenge), which group a greater number of Forest Fire Reports and EGIF motivations.

In addition, another category is included in the harmonization document that includes all those reports of deliberate fires that are not assigned a motivation and that are named as in EFFIS1: "500 Deliberate", in our case all those prior to 1989 and $67 \%$ of those that occur from that year until 2013. For the national database 2011-2013, the number of arson cases without specifying the reasons for them is $26.7 \%$, while in Castilla-La Mancha during the same period the figure rises to $43.6 \%$, a data that emphasises the idea of the damage caused by budget cuts in the investigation of causes in our region. The percentage distribution of the EFFIS classes, in which the intentionality has a known motivation, compared for Spain and Castilla-La Mancha, is as follows:
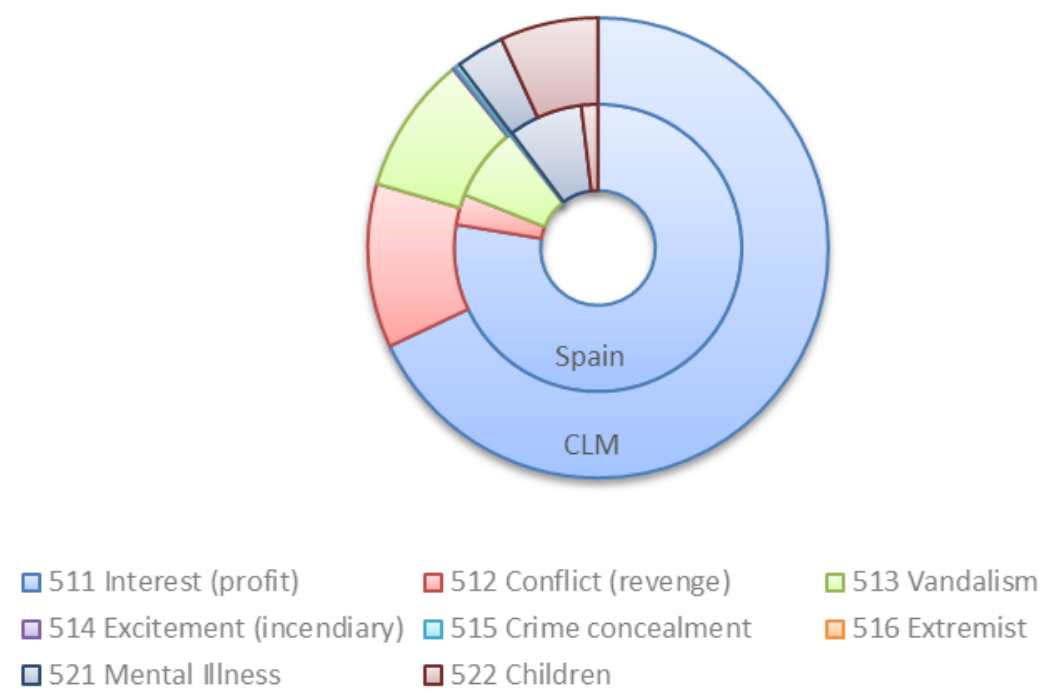

Figure 2 - Comparison of the percentage distribution of EFFIS3 classes within the category 500 Deliberate between Castilla-La Mancha (1989-2013) and Spain (2011-2013). Source EGIF. 
For both scales the main class is 511 Interest (profit), since it includes the cultural burnings carried out without a permit or outside the limited time interval for it, with a difference of ten percentage points in favour of the whole country, since the mentioned class includes almost $78 \%$ of all deliberate fires with known motivation in Spain. The EFFIS3 Conflict (revenge) class, second in terms of the number of reports in Castilla-La Mancha with $11.5 \%$, is nevertheless the fourth on a national scale with just 3.5\%, the main reason for the difference being the conflicts associated with hunting reserves, given the importance of this activity in the region. We found no significant differences in the fires caused by vandalism ( 8.5 and $9.6 \%$ respectively) while for the category 521 Mental illness the regional rate is much lower $(3.41 \%)$ than the national rate (8.35), very skewed, as we will see below, by the behavior of Galicia. Finally, the only class that changes category from Negligence to Deliberate is "Children" which is included, as we have already seen, in group 520 "Irresponsible", although with some adjustment problems.

Legally, pyromaniacs, whose number is also very marginal, should be included in the harmonisation of the Responsible (arson) group, thus separating them from the "serious" mentally ill who are not criminally responsible for their acts, which is why the harmonisation of the EGIF motivation "caused by pyromaniacs " with the EFFIS3 class 521 Mental Illnesses shows, in our opinion, a problem of conceptualization. The fact that they are included in group 520 Deliberate "irresponsible" presupposes that "pyromaniacs" are not criminally liable, an issue that is not exact in our criminal law. On the other hand, fires caused by diagnosed pyromaniacs are a small part of the events associated with this motivation, which serves, a priori, to accommodate any ignition produced by a person with a mental disorder.

In short, non-liability is established, except in anecdotal cases, on the basis of mental insanity, i.e. paranoia, schizophrenia and the Temporary Mental Disorder underlying either of these two illnesses, as well as for people with disabilities due to serious mental retardation. Pyromania, as a behavioural disorder, is considered in any case as an attenuating factor or, in interaction with other psychological problems, as a partial exonerating factor, so the harmonisation of this EGIF motivation should never be carried out in the group of "Irresponsible", since in Spain they are.

\section{The class EFFIS3 511 Interest (profit) and the problem of the criminalization of cultural burnings in Spain}

In addition to the doubts raised by the inclusion of cultural burnings without a permit within arson group, there is the fact that cultural burnings are classified in a group that includes other criminal motivations that are, although rare, in two of the cases clearly "mafia-like" (they are organized crime, some order and others execute), and all the others guilty of pursuing a direct economic benefit from the destruction of the forest, while in the case of cultural burnings - administratively illegal - such destruction may or may not take place, but in no case is the aim of who deliberately lights the fire.

As we have already pointed out, it has always been argued by the Spanish Ministry responsible for the environment that arson attacks include both 'malicious' cases (where there is wilful misconduct, the intention to burn the forest) and 'culpable' cases, where there is no intention to burn the forest but the (cultural) use of fire is normally consciously in contravention of the administrative rules on the matter and is therefore illegal. For the Ministry, the difference lies in the fact that in the deliberate ones the burning is carried out knowing that in that place and moment it is prohibited to carry out such burning, or the fires are abandoned before they are correctly extinguished, which, in its opinion, implies intentionality and not negligence in the cultural use of fire, although in both cases what underlies it is the traditional rural culture.

This criterion is certainly controversial, and in our opinion it is also not neutral, since calling arson what is not precisely 'intended' to burn the forest is a distorted picture of the problem for anyone who is not an expert in the forest. The use of the term 'forest' here is also intentional. 
The group of motivations that we have called "cultural", and which we point out in red in the table above, brings together the four sub-classes that we consider to be directly associated with cultural uses, two of which are in the majority and also generate a certain degree of confusion when compared with cultural negligence, since they have the same purpose and are almost identically named: vegetation management and agricultural burnings. If we compare the regional data with the national EGIF database for the period 2011-2013, we can see that the situation is even more problematic for the country as a whole, as can be seen in the following figure:

$\square$ To gain changes in land use
$\square$ To bring down the price of wood
$\square$ Earning wages in forest fire fighting
or restoration
$\square$ Provoked by hunters to facilitate
hunting
$\square$ Triggered to scare away animals
(wolves, wild boars)
$\square$ To promote the production of
forestry products
$\square$ Agricultural burnings
Herders and ranchers provoke them
to regenerate the grass

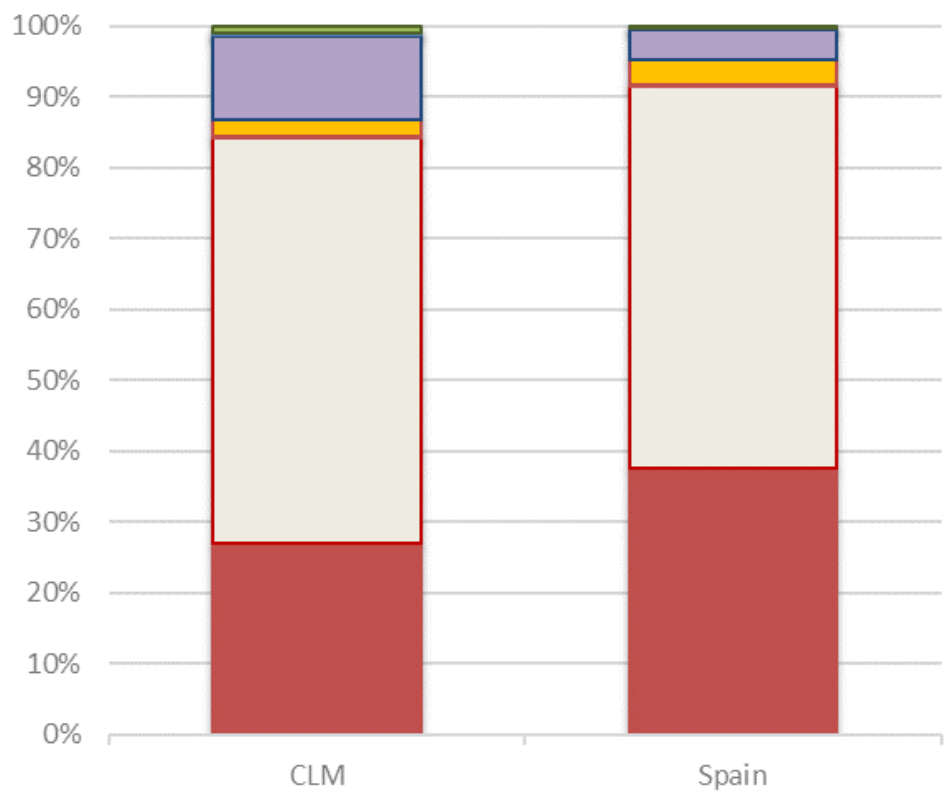

Figure 3 - Comparison of the percentage of Forest Fire Reports by motivation included in the EFFIS class 511 Interest (profit). Spain and Castilla-La Mancha. Source EGIF

In relation to the cultural uses of fire in the rural world, we cannot forget the fact that the vast majority of rural areas in our country, and specifically in Castilla-La Mancha, have a very old population, a consequence of the rural exodus experienced in recent decades. This population, when they are still able to work in agriculture, livestock or forestry, uses traditional management methods, i.e. they continue to burn to remove brushwood, brambles and plant residues or to regenerate the grass, with the consequent risk that these burns will spread to adjacent forest areas, due to their reduced physical capacity for fire control or to take all the necessary preventive measures.

As Enrique Martínez Ruiz (2001) argues, the depopulation of rural areas and the consequent abandonment of the countryside are the main cause of the serious problem of forest fires that has been dragging on in Spain for more than 35 years. However, sometimes the need for the farmer (farmer, rancher and forester) to remove vegetation is less well known, and the most expeditious and cheapest way to do this is by fire. But now the control of this fire is more difficult due to the accumulation and continuity of fuels and the uncontrolled burning due to negligent and deliberate causes provokes the majority of forest fires in Spain. In this context, public opinion, more in urban than in rural society, hardly understands the use of fire, which necessarily can and should be done by applying prescribed or controlled burning techniques (Martínez Ruiz, 2001: 6).

Illegal burning by farmers, herders and ranchers together accounts for $60 \%$ of deliberate fires of known motivation. Since the beginning of the development of agricultural activities, fire has been one of the common tools of agriculture and stockbreeding, indispensable throughout history for slashing and converting mountain areas into meadows and pastures. This has made it difficult today to observe a vegetation landscape that has not been shaped by fire (Vélez, 1986). Even today, the shepherd still uses it to limit the spread of woody plants and ensure the growth of herbaceous plants, in short, to 
maintain pastures; the farmer, in order to stop the invasion of wild plants and to favour growth conditions suitable for crops. This is the reason why the motivations that concentrate a greater number of fires are those related to the elimination of scrub or agricultural residues and the regeneration of pastures (Barroso and González, 2007), what we have called the cultural uses of fire in the rural world.

The harmonization document's own definitions specify that class 511 Interest (profit) includes (or should include) fires set to obtain a benefit, directly economic or other than monetary: fraud, insurance, liquidation of property, liquidation of business, elimination of parcels, competition for agricultural uses, hunting, pastoral or forestry use, to scare off wild animals, to obtain work in the firefighting area, change of land use, obtaining wages, etc. Whereas fires associated with class 411 Vegetation management are those used to control all types of vegetation, including regeneration of pasture, forest, pruning waste, etc. including prescribed fires and except for fires for agricultural purposes, as we know from experience reserved for class 412 and which collect all types of agricultural burnings. Both definitions show that, in the opinion of the Joint Research Centre of the European Commission, cultural burns, even illegal ones, should not be included in class 511 of deliberate fires for the sake of interest.

In short, Italy and Spain are the only two European countries that classify illegal (cultural) agroforestry/pastoral (forest) burning as a deliberate (intentional) fire, according to the internal regulations of both countries. In the absence of any other explanation, this is the reason why their arson rates are much higher, around 50\% of total fires, than those of the rest of the Mediterranean countries.

The differences in the consideration of the causes already appear in the 2008 report of the Attorney General's Office "In certain issues such as forest fires, the statistics provided by the different official bodies responsible for the matter almost necessarily have to differ, given that there is no clear and strict conceptual agreement. This undoubtedly explains the differences between the statistics provided by each of these institutions". Pursuing the divergence of data in the category of deliberate forest fires, it continues to point out that "intentionality as a parameter of voluntariness managed by the Administration may arouse some kind of suspicion, in the view of non-experts in the field, however, an example is enough to explain what we say here. An agricultural burning on a farm without asking for a permit can be an arson attack for the administration, and for penal parameters it can be unpunished" (Fiscalía General del Estado, 2008: 38).

However, the Attorney General's Office claims to use the classification of the causes of forest fires by the Ministry responsible for the Environment, and indicates that only those caused by negligence or accidents and those that are deliberate are of interest to the Attorney General's Office, according to the criteria of the Prosecutor General's Office for the Environment, establishing the definition of each of these categories. Thus, it considers accidents to be "activities in which the perpetrator could not have foreseen that a forest fire would occur. This activity is not associated with forest fires and, if they occur, is due to fortuitous causes", and negligence such as "human activities which cause a forest fire without the person involved intending to cause it, even though he has carried out an activity which may cause a fire or has omitted the safety measures which prevented it from occurring". Finally, for arson, it states that "In general, we can consider actions whose purpose is the deliberate generation of a forest fire" (Fiscalía General del Estado, 2015: 120). Therefore, the public prosecutor's office explains that it understands, like most citizens, that an arson attack is one in which the perpetrator intends to start a forest fire.

In addition to the perplexity and concern caused by the obvious lack of communication and coordination between the highest authorities responsible for forest fire risk management in our country, the General Directorate of Biodiversity and the General State Prosecutor's Office, it is clear that the criterion described above of considering "criminally negligent" fires to be arson is not in line with our general legal system. Our legislation has well defined the intentionality, the volitional element in Criminal Law, drawing a clear distinction from recklessness, which in this case also involves criminal liability but in a lessened form. In the latter case, the criminal liability of those who burn the forest due to negligence/imprudence is less than that of those who wish to burn it. 
The information provided by the Attorney General's Office in its annual reports is devastating. On the other hand, the quality of the data is necessarily higher, since it is not the prosecution that is counted, but the cases in which there are accused persons, so that the information on the specific cause or motivation that has triggered the claim is assumed to be sufficiently reliable to initiate legal proceedings with guarantees that it will succeed.

Based on the data on claims investigated with an accused person, organized by cause and compiled in the annual reports of the Attorney General's Office, we have prepared three statistics. The breakdown by cause is included from the 2009 report, with percentage data, so we first convert them to absolute numbers using a rule of three that uses the number of fires with accused/detained person offered by the same memory. Therefore, we directly use the prosecution's percentage as the intentionality rate that allows us to analyze the performance of the entire data set from the 2007 report. The evolution of causation in the statistics of the Attorney General's Office since the systematization of the data began is as follows:

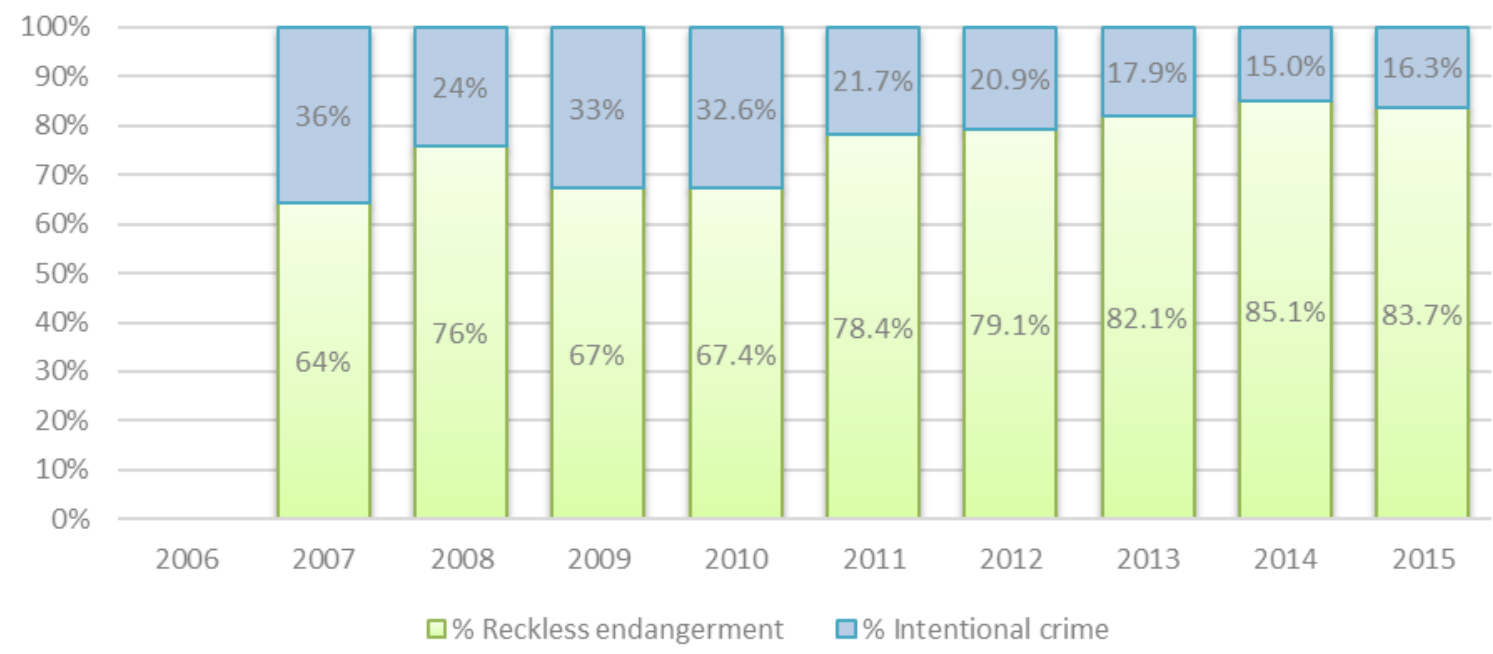

Figure 4 - Percentage of court cases with accused persons by general causality group. Spain 2007-2015. Source Proceedings of the Attorney General's Office.

Cultural burnings are also the main cause of fires investigated by the courts, along with accidents caused by machinery, power lines or vehicles. All this leads us to review the reasoning behind the inclusion of burnings without a permit in the category of arson by the General Directorate of Biodiversity. Negligence with non-compliance with administrative legislation is reckless endangerment for both pastoralists and peasants and for those responsible for railways, power lines, machinery owners or smokers who do not comply with the respective sectoral regulations. That is to say, practically any negligence should be considered arson, since the same legal elements apply as for burning without a permit. Let us remember, for example, that, in general, smoking is prohibited on forest land, all rural land not used for agriculture, inside High Risk Areas, so any accident caused by a cigarette butt should be considered legally the same as a burning of pastures without a permit. The proof of this is how the Attorney General's Office "welcomes" the accusations of several people in cases involving power lines or the accusation of mayors for fires originating in landfills.

In order to distinguish malicious cultural uses from cultural burnings included in the group of negligence, the Attorney General's Office calls this set of motivations "inappropriate traditional practices" and considers them malicious on the basis of the assessment of dolus eventualis, since, although there is no wilful intent, the intention to burn the forest, the perpetrator, due to his knowledge and experience, can reasonably understand that the most likely consequence of his act is that the fire will break out (that the fire will advance without control). The procedure thus moves from being prosecuted as a punishable offence to being prosecuted as a criminal offence, a matter which satisfies 
the interest of the Attorney General's Office in obtaining exemplary sentences. The concept of dolus eventualis is repeated in the reports of the Attorney General's Office and is not very comprehensible to a lay person in criminal law, however, we consider that its interpretation is important for understanding the criminal response as an essential mechanism for managing the risk of forest fires.

\section{Discussion and conclusions}

A revision of the criteria for classifying forest fires in the official Spanish EGIF database is urgent, adapting it to the original EFFIS criteria, as it would contribute to a better general (socio-economic, cultural and territorial) and political understanding of the problem.

This review should be applied to the entire EGIF historical series, one of the best statistics in the world for the study of forest fires, a review that according to the experience acquired in our research does not raise any serious methodological problem.

However, the general and deeper problem in Spain is the need for the paradigm of fire ecology to extend beyond the academic and technical realm to the entire population and the legal framework. In the past decades and in some countries, however, a slight and gradual change in perspective has occurred, such that for fire managers, preserves managers, researchers, and non-government organizations, the fire ecology as well as the management of fire by rural communities have been incorporated into what is now referred to as "integral fire management". This term may be defined as the fusion of firefighting and prevention with the ecological use of fire and community fire management in order to preserve nature and to make the land productive (Rodríguez-Trejo et al. 2011). Now one of the challenges is to better understand the traditional use of fire by the rural communities and to identify those that apply good use of fire and invite them to extend this practice to other communities. It is also necessary to convince more universities to participate in the ecological and social research of fire in the different regions of the countries and to educate the public to understand and support integral fire management. The final challenge is to connect in a sustainable way, classic fire management that has been centered on prevention and firefighting, with the ecological use of fire and, above all, with fire management of the rural communities (Rodríguez-Trejo et al. 2011: 49).

\section{References}

APAS (Asociación para la Promoción de Actividades Socioculturales), IDEM (Instituto de Estudios del Medio) (2004) Estado del conocimiento sobre las causas de los incendios forestales en España, Asociación para la Promoción de Actividades Socioculturales. http://www.idem21.com/descargas/pdfs/CAUSAS_IF.pdf.

Barroso Fernández J, González Bascones V, (2007) Motivaciones de incendios forestales intencionados en España. In 'Wildfire 2007, 4 ${ }^{\text {a }}$ Conferencia Internacional sobre Incendios Forestales', Sevilla. http://www.eufirelab.org/toolbox2/library/upload/2298.pdf.

Carracedo Martín V, Diego Liaño C, García Codrón JC, Rasilla Álvarez DF (2009) 'Los incendios forestales', Barcelona, Davinci Continental, S.L., Collection "Nueva Geoambiente XXI”, 250 p.

Castro R, Simarro ME, Priego C, Lafuente R, Sancho A. (2007) Investigación social sobre los incendios forestales en Andalucía. 'Wildfire 2007, 4 Conferencia Internacional sobre Incendios Forestales', Sevilla. http://decastro.ricardo.googlepages.com/Investigacinsocialeincendiosforestal.pdf.

CLIF (1997a) Apuntes para la codificación en oficina del Parte de Incendio Forestal, Madrid, Comité de Lucha Contra Incendios Forestales, DGCONA, Ministerio de Medio Ambiente.

CLIF (1997b) Instrucciones para rellenar el Parte de Incendio Forestal, Madrid, Comité de Lucha Contra Incendios Forestales, DGCONA, Ministerio de Medio Ambiente. 
Joint Research Centre (JRC) (2013): Harmonized classification scheme of fire causes in the EU adopted for the European Fire Database of EFFIS, Executive Report 25923, Luxembourg: Publications Office of the European Union, 51 p. http://publications.jrc.ec.europa.eu/repository/bitstream/JRC80682/lb-na-25-923-en-n.pdf.

Fiscalía General del Estado (2008) Memoria 2008. Memoria de la actividad desplegada por el Ministerio Fiscal a lo largo del año 2007. http://www.mapama.gob.es/es/ceneam/grupos-detrabajo-yseminarios/fiscalias-de-medio-ambiente/memo_fiscalia2008_tcm7-13294.pdf.

Fiscalía General del Estado (2012) Memoria 2012. Memoria de la actividad desplegada por el $\begin{array}{llllll}\text { Ministerio Fiscal a lo largo } & \text { del } & \text { año }\end{array}$ https://www.fiscal.es/fiscal/publico/ciudadano/documentos/memorias_fiscalia_general_estado/!ut /p/a0/04_Sj9CPykssy0xPLMnMz0vMAfGjzOI9HT0cDT2DDbwsgozNDBwtjNycnDx8jAwszPQ Lsh0VAQluD0w!/?selAnio=2012.

Fiscalía General del Estado (2015) Memoria 2015. Memoria de la actividad desplegada por el $\begin{array}{lllllll}\text { Ministerio Fiscal a } & \text { lo } & \text { largo } & \text { del } & \text { año } & 2014 .\end{array}$ https://www.fiscal.es/memorias/memoria2015/FISCALIA_SITE/recursos/pdf/MEMFIS15.pdf.

Martín Isabel MP, Chuvieco Salinero E, Aguado I (1998) La incidencia de los incendios forestales en España. Serie Geográfica, vol. 7, 23-36.

Martínez Navarro JM (2017) La gestión territorial del riesgo antrópico de ignición forestal en CastillaLa Mancha, PhD dissertation, Department of Geography and Spatial Planning, University of Castilla-La Mancha.

Martínez Ruiz E (2001) 'Manual de quemas controladas. El manejo del fuego en la prevención de incendios forestales'. Madrid, TRAGSA \& Ediciones Mundi Prensa, 178 p.

Molinero Hernando F, Cascos C, García A, Baraja E (2008a) Dinámica de los incendios forestales en Castilla y León., Boletín de la Asociación de Geógrafos Españoles, 48, 39-70.

Molinero Hernando F, García A, Cascos C, Baraja E, Guerra JC (2008b) La percepción local de los incendios forestales y sus motivaciones en Castilla y León. Ería, 76, 213-229.

Pérez Vilariño J (2004) Incendios forestales y reconstrucción social del monte. In 'Reflexiones sociológicas: homenaje a José Castillo Castillo’ (Ed. Díez Nicolás J et al.), pp. 651-678. (Centro de Investigaciones Sociológicas: Madrid).

Pérez Vilariño J, Delgado Fernández JL (1995) Análisis del riesgo de incendio forestal en Galicia. Agricultura y Sociedad, 77, 109-124.

Priego C, Lafuente R (2007) 'La Investigación Social como una nueva herramienta contra la lucha de los incendios forestales en Andalucía'. http://www.iesaa.csic.es/archivos/Comunicaciones/PRIEGO-Y-LAFUENTE.pdf.

Rodríguez-Trejo DA, Martínez-Hernández PA, Ortiz-Contla, H, Chavarría-Sánchez MR, HernándezSantiago F (2011) The present status of fire ecology, traditional use of fire, and fire management in Mexico and Central America, Fire Ecology, 7(1), 40-56. doi:10.4996/fireecology.0701040.

Vélez Muñoz R (1986) Incendios forestales y su relación con el medio rural. Revista de Estudios AgroSociales, 136, 195-224.

Vélez Muñoz R (1999) El período 1848-1997 en la defensa contra incendios forestales en España. In 'Incendios históricos: una aproximación multidisciplinar' (Ed. E Araque Jiménez) pp. 13-38. (Universidad Internacional de Andalucía: Jaén). 